\title{
PENGARUH PENDIDIKAN KESEHATAN TERHADAP KECEMASAN PRIMIGRAVIDA DALAM MENGHADAPI PERSALINAN
}

\author{
Mukhoirotin $^{1}$, Ibrahim Rahmat ${ }^{2}$, Risanto Siswosudarmo ${ }^{3}$
}

\begin{abstract}
Background: During a process of labor and delivery a primigravida mother tends to have increased fear and anxiety, because of pain and discomfort. She is worry about her safety and her baby. Unless it is well managed it might cause same complication such us premature labor, prolonged labor, and fetal death. Health education is one effort that can be done by health workers to decrease anxiety and prepare mother in facing the process of labor and delivery.

Objective: To find out the influence of health education to primigravida anxiety in facing the process of labor and delivery.

Method: The study was a quasy experiment by pretest-postest control group design. Subjects were all primigravidas at Peterongan Public Health Centre (Puskesmas) area of Jombang Regency. A total of sixty six respondents meeting the inclusion and exclusion criteria were recruited. They were devided into two groups, the treated group received health education and booklet $(n=33)$ and the control group received health education only $(n=33)$. The sampling tehnique were using consecutive sampling and cluster randomized trial. The instrument used to measure anxiety was Zung Self-Rating Anxiety Scale. Data were processed using computer program. Paired and independent sample t-tests were used for statistical analysis .

Results and Discussion: The anxiety scores before treatment was comparable between the two groups ( $p>0.05)$. This scores decreased significantly after treatment from 36.79 to 29.79 in the treated group, and from 36.85 to 32.03 in the control group $(p<0.05)$. The post treatment score was significanly different between the treated and the control groups $(29.79 \pm 4.14$ vs. $32.03 \pm 4.01 ; p<0.05)$.

Conclution: Health education with booklet was more effective to decrease anxiety in the primigravida in facing labor compared to health education only.
\end{abstract}

Keywords: health education, booklet, anxiety, primigravida.

\begin{abstract}
ABSTRAK
Latar Belakang: Selama proses persalinan dan melahirkan seorang ibu primigravida cenderung mengalami peningkatan ketakutan dan kecemasan, karena rasa sakit dan ketidaknyamanan. Ibu khawatir tentang keselamatan dirinya dan bayinya. Apabila hal ini tidak dikelola dengan baik dapat menyebabkan beberapa komplikasi seperti persalinan prematur, partus lama, dan kematian janin. Pendidikan kesehatan merupakan salah satu upaya yang dapat dilakukan oleh tenaga kesehatan untuk menurunkan kecemasan dan mempersiapkan ibu dalam menghadapi proses persalinan dan melahirkan.

Tujuan: Untuk mengetahui pengaruh pendidikan kesehatan terhadap kecemasan primigravida dalam menghadapi persalinan.

Metode: Penelitian ini adalah quasi experiment dengan pendekatan pretest-postest control group design. Subyek penelitian adalah semua primigravida di wilayah Puskesmas Peterongan kabupaten Jombang. Sebanyak 66 responden yang memenuhi kriteria inklusi dan eksklusi direkrut.
\end{abstract}

\footnotetext{
1,2 Program Studi Magister Keperawatan, Fakultas Kedokteran Universitas Gadjah Mada Yogyakarta

3 Bagian Obstetri dan Ginekologi, Fakultas Kedokteran Universitas Gadjah Mada Yogyakarta
} 
Subyek penelitian dibagi menjadi dua kelompok, kelompok perlakuan yang mendapatkan pendidikan kesehatan dan booklet $(n=33)$ dan kelompok kontrol yang mendapatkan pendidikan kesehatan $(n=33)$. Tehnik sampling menggunakan consecutive sampling dan cluster randomized trial. Instrumen yang digunakan untuk mengukur kecemasan adalah Zung Self-Rating Anxiety Scale. Data diolah dengan menggunakan program komputer. Paired sample t-test dan independent sample t-test digunakan untuk analisis statistik.

Hasil dan Pembahasan: Skor kecemasan sebelum perlakuan adalah sebanding antara kedua kelompok $(p>0,05)$. Skor ini menurun secara signifikan setelah perlakuan dari 36,79-29,79 pada kelompok perlakuan, dan dari 36,8532,03 pada kelompok kontrol $(p<0,05)$. Skor setelah perlakuan terdapat perbedaan yang signifikan antara kelompok perlakuan dan kontrol $(29,79 \pm 4,14$ vs. $32,03 \pm 4,01, p<0,05)$.

Kesimpulan: Pendidikan kesehatan dengan booklet lebih efektif untuk menurunkan kecemasan primigravida dalam menghadapi persalinan dibandingkan dengan pendidikan kesehatan saja.

Kata Kunci: pendidikan kesehatan, booklet, kecemasan, primigravida.

\section{PENDAHULUAN}

Kehamilan, persalinan, dan menjadi seorang ibu merupakan peristiwa dan pengalaman penting dalam kehidupan seorang wanita. Sebagaimana tahap transisi lain dalam fase kehidupan, peristiwa itu dapat pula menimbulkan stres. ${ }^{1}$ Bagi seorang ibu primigravida ketika menghadapi proses persalinan cenderung mengalami kecemasankarenaproses persalinan adalah sesuatu hal baru yang akan dialaminya. ${ }^{2}$

Kecemasan merupakan salah satu penyebab terjadinya partus lama dan kematian janin. Partus lama memberikan sumbangsih $5 \%$ terhadap penyebab kematian ibu di Indonesia. Hasil Survei Demografi dan Kesehatan Indonesia (SDKI) tahun 2012 menunjukkan bahwa Angka Kematian Bayi (AKB) adalah 32/1000 kelahiran hidup, Angka Kematian Ibu (AKI) sebesar 359/100.000 kelahiran hidup sedangkan target Millenium Developmen Golds (MDG's) pada tahun 2015 untuk AKB adalah 23/1000 kelahiran hidup dan untuk AKI 102/100.000 kelahiran hidup. AKB dan AKI sejak tahun 1991 cenderung mengalami penurunan. ${ }^{3}$ Meskipun AKB di Indonesia terus menurun namun tingkat kematian bayi di Indonesia masih tergolong tinggi dibandingkan dengan negara-negara anggota ASEAN, yaitu 4,2 kali lebih tinggi dari Malaysia, 1,2 kali lebih tinggi dari Filipina dan 2,2 kali lebih tinggi dari Thailand. ${ }^{4}$
Sedangkan AKI di Indonesia menempati urutan tertinggi di kawasan ASEAN. ${ }^{3}$

AKB di Kabupaten Jombang tahun 2012 sebesar $12,15 / 1.000$ kelahiran hidup. Angka ini menunjukkan bahwa AKB di Kabupaten Jombang berada di bawah batas toleransi target MDG's tahun 2015, akan tetapi angka ini masih di atas dari target AKB yang ditetapkan dalam Rencana Pembangunan Jangka Menengah Daerah (RPJMD) Kabupaten Jombang yaitu sebesar $7,88 / 1.000$ kelahiran hidup pada tahun 2013. AKI di Kabupaten Jombang pada tahun 2012 adalah 102,91. Angka capaian ini sudah mendekati target MDG's tahun 2015, akan tetapi belum mencapai target AKI yang ditetapkan dalam RPJMD Kabupaten Jombang. AKI di Kabupaten Jombang didapatkan pada 16 wilayah kerja Puskesmas diantaranya adalah Peterongan, Bandar Kedungmulyo, Pulorejo, Tambak Rejo dan Bareng, dimana nilai dari masing-masing wilayah adalah $9,5 \%$ dan 11 wilayah kerja Puskesmas lainnya masing-masing $4,8 \%{ }^{5}$

Kecemasan pada wanita primigravida dapat timbul akibat kekhawatiran akan proses kelahiran yang aman untuk dirinya dan anaknya. ${ }^{6}$ Kecemasan pada awal kehamilan merupakan faktor risiko terjadinya preeklampsi. ${ }^{7}$ Apabila kecemasan berlanjut sampai akhir kehamilan dan persalinan akan berdampak tidak saja pada ibu tapi juga terhadap bayinya. Hal ini terjadi karena kecemasan dapat 
menyebabkan peningkatan sekresi adrenalin. Peningkatan sekresi adrenalin dapat menyebabkan kontraksi uterus berlebihan sehingga terjadi vasokonstriksi akibatnya aliran darah utero-placenta menurun $^{8}$, mengakibatkan terjadinya hipoksia dan bradikardi janin yang akhirnya akan terjadi kematian janin ${ }^{9}$ dan dapat menghambat kontraksi, sehingga memperlambat persalinan. ${ }^{10}$ Wanita hamil yang disertai kecemasan, berisiko untuk terjadinya persalinan prematur. ${ }^{11}$

Kematian ibu dan janin sering tidak diakibatkan oleh ketidakmampuan tehnik atau kelalaian, tetapi juga karena kurangnya pendidikan kesehatan ibu tentang persalinan. Pengetahuan yang terbatas pada ibu primigravida tentang persalinan meningkatkan kecemasan. ${ }^{12}$ Untuk mengatasi hal ini dan mencegah kecemasan primigravida dalam menghadapi persalinan, salah satu upaya yang dapat dilakukan oleh tenaga kesehatan adalah dengan memberikan pendidikan kesehatan tentang persiapan persalinan dan proses melahirkan ${ }^{6}$ serta manajemen nyeri selama melahirkan ${ }^{13}$ sehingga kecemasan ibu berkurang dan lebih siap dalam menghadapi persalinan.

Pendidikan kesehatan merupakan suatu bentuk intervensi keperawatan yang mandiri untuk membantu klien baik individu, keluarga, kelompok maupun masyarakat dalam mengatasi masalah kesehatan melalui kegiatan pembelajaran, yang didalamnya perawat berperan sebagai perawat pendidik. ${ }^{14}$ Penelitian menunjukkan bahwa program pengajaran yang direncanakan membantu mengurangi kecemasan ibu primigravida dan studi ini menunjukkan bahwa ada korelasi positif antara pengetahuan dan penurunan kecemasan menghadapi persalinan pada ibu primigravida. ${ }^{12}$ Identifikasi kecemasan dan stres, membantu perawat untuk merencanakan memberikan perawatan holistik yang membantu ibu untuk meminimalkan kecemasan. Memberikan dukungan psikologis adalah salah satu kebutuhan yang paling penting selama persalinan dan kelahiran dan kebutuhan akan pendidikan, bimbingan dan penyuluhan penting untuk primigravida ketika mereka stres dan cemas selama kehamilan dan persalinan.

Berdasarkan fenomena di atas, Penulis tertarik untuk melakukan penelitian dengan judul "Pengaruh pendidikan kesehatan terhadap kecemasan primigravida dalam menghadapi persalinan". Tujuan penilitian ini adalah untuk mengetahui perbedaan pengaruh antara pendidikan kesehatan dengan booklet dan pendidikan kesehatan tanpa booklet terhadap kecemasan primigravida dalam menghadapi persalinan.

\section{METODE}

Jenis penelitian ini adalah quasi experimental dengan pendekatan pretest-postest control group design. Populasi dalam penelitian ini adalah semua primigravida di wilayah kerja Puskesmas Peterongan Jombang pada periode bulan Juni sampai dengan Juli 2014 sebanyak 90 responden dengan jumlah sampel sebanyak 66 responden yang memenuhi kriteria inklusi yaitu primigravida trimester III (usia kehamilan $\geq 28$ minggu), bertempat tinggal di wilayah kerja Puskesmas Peterongan Jombang, ibu hamil dengan indikasi partus normal, dan bersedia menjadi responden. Subyek penelitian dibagi menjadi duakelompok yaitu kelompok perlakuan yang mendapatkan pendidikan kesehatan dan booklet $(n=33)$ dan kelompok kontrol yang mendapatkan pendidikan kesehatan $(n=33)$. Tehnik pengambilan sampel dengan menggunakan consecutive sampling dan cluster randomized trial. Instrumen yang digunakan untuk mengukur kecemasan adalah Zung SelfRating Anxiety Scale. Kecemasan diukur sebelum diberikan pendidikan kesehatan dan satu minggu setelah diberikan pendidikan kesehatan. Data dianalisis menggunakan paired sample t-testdan independent sample t-test dengan tingkat kemaknaan $\alpha=0,05$. 


\section{HASIL DAN PEMBAHASAN}

Karakteristik responden dalam penelitian ini meliputi: 1) Umur; 2) Pendidikan; 3) Pekerjaan; dan 4) Dukungan sosial. Hasil penelitian menunjukkan tidak ada perbedaan karakteristik yang bermakna antara kelompok pendidikan kesehatan dan booklet dengan kelompok pendidikan kesehatan. Hal ini terlihat dari nilai signifikan ( $p$ ) dari semua karakteristik responden lebih besar dari nilai $p>0,05$. Hal ini berarti salah satu persyaratan untuk melakukan penelitian eksperimen sudah terpenuhi, karena kondisi awal responden pada kedua kelompok memiliki karakteristik subyek yang seimbang atau dengan kata lain kedua kelompok adalah homogen, seperti terlihat pada tabel 1.

Tabel 1. Karakteristik subyek penelitian dan homogenitas

\begin{tabular}{|c|c|c|c|c|c|c|}
\hline \multirow{2}{*}{\multicolumn{2}{|c|}{ Variabel }} & \multicolumn{2}{|c|}{ Pendidikan dan Booklet } & \multicolumn{2}{|c|}{ Pendidikan } & \multirow{2}{*}{$\frac{\text { Nilai } p}{p}$} \\
\hline & & $n$ & $\%$ & $\mathrm{n}$ & $\%$ & \\
\hline \multirow[t]{3}{*}{1.} & Umur & & & & & \\
\hline & a. $<20 ;>35$ tahun & 4 & 12,10 & 2 & 6,10 & 0,39 \\
\hline & b. $20-35$ tahun & 29 & 87,90 & 31 & 93,90 & \\
\hline \multirow[t]{3}{*}{2.} & Pendidikan & & & & & \\
\hline & c. Rendah & 9 & 27,30 & 7 & 21,20 & 0,57 \\
\hline & a. Tinggi & 24 & 72,70 & 26 & 78,80 & \\
\hline \multirow[t]{3}{*}{3.} & Pekerjaan & & & & & \\
\hline & a. Tidak bekerja & 25 & 75,80 & 21 & 63,60 & 0,28 \\
\hline & b. Bekerja & 8 & 24,20 & 12 & 36,40 & \\
\hline \multirow[t]{6}{*}{4.} & $\begin{array}{l}\text { Dukungan sosial } \\
\text { SSQN }\end{array}$ & & & & & \\
\hline & a. Sedikit & 22 & 66,70 & 15 & 45,50 & 0,09 \\
\hline & b. Banyak & 11 & 33,30 & 18 & 54,50 & \\
\hline & SSQS & & & & & \\
\hline & a. Rendah & 16 & 48,50 & 13 & 39,40 & 0,46 \\
\hline & b. Tinggi & 17 & 51,50 & 20 & 60,60 & \\
\hline
\end{tabular}

SSQN: Social Support Questionnaire Number

SSQS: Social Support Questionnaire Satisfaction

Sebelum diberikan perlakuan pendidikan kesehatan tentang persalinan, terlebih dulu dilakukan pengukuran awal terhadap kecemasan melalui pre test. Kemudian dilakukan uji independent sample $t$ test untuk mengetahui kondisi awal kecemasan ibu primigravida dalam menghadapi persalinan pada kelompok pendidikan kesehatan dan booklet serta pada kelompok pendidikan kesehatan. Berdasarkan hasil pengukuran tersebut, didapatkan nilai rata-rata kecemasan dari kelompok perlakuan dan kelompok kontrol tidak menunjukkan perbedaan yang bermakna seperti terlihat pada tabel 2 .

Tabel 2. Skor kecemasan pra-perlakuan

\begin{tabular}{lcccc}
\hline \multicolumn{1}{c}{ Kelompok } & Mean & SD & Beda Mean $(95 \% \mathrm{Cl})$ & $\mathrm{p}$ \\
\hline Pendidikan dan Booklet & 36,79 & 5,55 & $-0,06(-2,51-2,39)$ & 0,96 \\
Pendidikan & 36,85 & 4,33 & & \\
\hline
\end{tabular}


Setelah diberikan perlakuan pendidikan kesehatan dan booklet pada kelompok perlakuan dan pendidikan kesehatan pada kelompok kontrol, kemudian dilakukan pengukuran kecemasan yang dilakukan 1 minggu setelah perlakuan. Berdasarkan hasil pengukuran tersebut, didapatkan nilai rata-rata kecemasan dari kelompok perlakuan dan kelompok kontrol mengalami penurunan antara pre test dan post test dimana pada kelompok pendidikan dan booklet rata-rata skor kecemasan sebesar 29,79 dengan standar deviasi 4,14 sedangkan pada kelompok pendidikan rata-rata skor kecemasan sebesar 32,03 dengan standar deviasi 4,01.
Perbedaan selisih rata-rata antara kelompok pendidikan kesehatan dan booklet dan pendidikan kesehatan adalah -2.24 dengan $p$ value sebesar 0,03 $(p<0,05)$. Analisis statistik dengan menggunakan uji independent sample t-test menunjukkan bahwa terdapat perbedaan yang bermakana pada selisih rata-rata kecemasan primigravida dalam menghadapi persalinan antara kelompok perlakuan dan kelompok kontrol yang berarti pendidikan kesehatan dengan booklet dapat menurunkan kecemasan primigravida dalam menghadapi persalinan lebih besar dibandingkan dengan pendidikan kesehatan tanpa booklet seperti terlihat pada tabel 3 .

Tabel 3. Skor kecemasan pasca-perlakuan

\begin{tabular}{lcccc}
\hline \multicolumn{1}{c}{ Kelompok } & Mean & SD & Beda Mean $(95 \% C l)$ & P \\
\hline Pendidikan dan Booklet & 29,79 & 4,14 & $-2.24(-4,25--0,24)$ & 0,03 \\
Pendidikan & 32,03 & 4,01 & & \\
\hline
\end{tabular}

Berdasarkan hasil uji paired sample t-test didapatkan perbedaan yang bermakna secara statistik rata-rata kecemasan antara pra-perlakuan dan pasca-perlakuan pada kedua kelompok.
Penurunan rata-rata skor kecemasan tertinggi terjadi pada kelompok pendidikan dan booklet, seperti terlihat pada tabel 4 .

Tabel 4. Perbedaan rata-rata data pra-perlakuan dan pasca-perlakuan kecemasan

\begin{tabular}{lcccc}
\hline \multicolumn{1}{c}{ Kelompok } & $\begin{array}{c}\text { Pra-Perlakuan } \\
\text { Mean (SD) }\end{array}$ & $\begin{array}{c}\text { Pasca-Perlakuan } \\
\text { Mean (SD) }\end{array}$ & $\begin{array}{c}\text { Beda Mean } \\
(95 \% \mathrm{C})\end{array}$ & $\mathrm{P}$ \\
\hline Pendidikan dan Booklet & $36,79 \pm 5,55$ & $29,79 \pm 4,14$ & $7,00(5,11-8,89)$ & 0,00 \\
Pendidikan & $36,85 \pm 4,33$ & $32,03 \pm 4,01$ & $4,82(3,09-6,55)$ & 0,00 \\
\hline
\end{tabular}

Kecemasan dalam mengahadapi persalinan merupakan suatu perasaan cemas, khawatir dan ketegangan yang melanda kaum ibu pada saat mereka tengah hamil ataupun sedang mempersiapkan persalinannya. Kecemasan dalam menghadapi persalinan dapat dikatakan sebagai suatu respon yang timbul dalam menghadapi persalinan yang disebabkan perubahan yang dialami dalam kehamilan dan juga merupakan suatu pengalaman baru dalam kehidupannya. ${ }^{15} \mathrm{Kecemasan}$ pada wanita primigravida dapat timbul akibat kekhawatiran akan proses kelahiran yang aman untuk dirinya dan anaknya. Banyak wanita takut mengalami nyeri selama proses bersalin atau mutilasi (hilangnya bagian tubuh) karena mereka tidak mengerti anatomi dan proses melahirkan. Wanita juga menyatakan rasa khawatirnya akan perilaku yang pantas selama proses bersalin dan bagaimana individu yang merawat mereka akan menerima perilaku mereka. ${ }^{6}$

Hasil penelitian ini menunjukkan bahwa kecemasan yang dialami oleh kelompok perlakuan dan kelompok kontrol terjadi karena persalinan merupakan pengalaman pertama, berharap bayinya segera lahir dan terbebas dari ketidaknyamanan fisik, takut pada saat persalinan terjadi hal yang tidak diinginkan atau masalah baik pada ibu maupun 
bayinya, takut nyeri pada saat melahirkan, takut jalan lahirnya robek dan dijahit, takut tidak kuat mengejan, mendapat cerita yang menakutkan dari tetangga bahwa saat melahirkan sakit, dan takut operasi serta persalinannya tidak berjalan lancar. Hal ini sesuai dengan pendapat sebelumnyayang menyatakan bahwa ibu hamil akan dibayangi dan dihantui rasa cemas dan takut akan segala sesuatu yang mungkin dapat terjadi pada dirinya dan bayinya, pertanyaan dan bayangan saat melahirkan apakah secara normal, bagaimana cara mengejan, apakah ada sesuatu yang terjadi saat persalinan, apakah bayinya sehat, pertanyaan-pertanyaan tersebut sering muncul dalam benak ibu hamil. ${ }^{15}$ Pendapat lain menyatakan bahwa perubahan psikologis yang terjadi menjelang akhir trimester ketiga diantaranya disebabkan oleh: 1) Ibu berharap-harap untuk mengakhiri kehamilan, terbebas dari ketidaknyamanan fisik dan menyambut si buah hati yang sudah ditunggu; 2) Ibu lebih introspektif dan lebih banyak memikirkan dan mengkhawatirkan persalinan, pelahiran dan bayi; 3) Ibu mulai protektif terhadap bayi yang sedang berkembang dan mencoba menghindari hal-hal yang dapat mengganggu kesejahteraan janin; 4) Pikiran tentang kematian atau cidera yang dapat muncul pada ibu dan bayi. ${ }^{16}$

Penyebab kecemasan pada responden juga sesuai dengan hasil penelitian sebelumnya yang menyatakan bahwa penyebab kecemasan wanita hamil diantaranya adalah kurangnya pengetahuan tentang proses fisiologi normal melahirkan dan takut mati karena komplikasi pada saat melahirkan, hal ini terjadi karena akses masyarakat yang rendah terhadap pelayanan kesehatan. ${ }^{17}$

Hasil uji satistik paired sample t-test menunjukkan bahwa rata-rata skor kecemasan pra-perlakuan dan pasca-perlakuan terdapat penurunan yang bermakna pada kelompok yang mendapat pendidikan kesehatan denganbooklet dan pada kelompok pendidikan juga terdapat penurunan rata-rata skor kecemasan pra-perlakuan dan pasca-perlakuan yang bermakna.
Pendidikan kesehatan merupakan suatu bentuk intervensi keperawatan mandiri untuk membantu klien baik individu, keluarga, kelompok maupun masyarakat dalam mengatasi masalah kesehatan melalui kegiatan pembelajaran, yang didalamnya perawat berperan sebagai perawat pendidik. ${ }^{14}$ Pendidikan kesehatan adalah suatu kegiatan atau usaha untuk membantu individu, kelompok atau masyarakat dalam meningkatkan kemampuan (perilakunya), untuk mencapai kesehatan secara optimal termasuk emosi-psikologisnya. Adapun hasil pendidikan kesehatan tersebut, yaitu dalam bentuk perilaku yang menguntungkan kesehatan. Baik dalam bentuk pengetahuan dan pemahaman tentang kesehatan, yang diikuti dengan kesadaran yaitu sikap yang positif terhadap kesehatan, yang akhirnya diterapkan dalam tindakan-tindakan yang menguntungkan kesehatan, dalam hal ini dapat mengendalikan kecemasan saat menghadapi persalinan. Pendidikan kesehatan tentang persalinan dapat membuat ibu dan pasangan belajar lebih banyak dan menjadi semakin tidak khawatir perihal persalinan dan pelahiran serta mulai menemukan cara-cara untuk menghadapi stres dari kehamilan akhir. ${ }^{16}$

Setelah mendapatkan pendidikan kesehatan tentang persalinan, responden menyatakan memiliki pengetahuan dan pemahaman tentang persalinan sehingga dapat mengurangi perasaan cemas, gelisah dan takut karena responden sebelumnya belum tahu tentang proses persalinan dan melahirkan menjadi lebih tahu. Hal ini sesuai dengan pendapat sebelumnya yang meyatakan bahwa dengan memahami sesuatu yang sedang terjadi ketika persalinan dapat meningkatkan perasaan mengontrol ibu terhadap persalinan. ${ }^{1}$

Hasil penelitian ini sesuai dengan hasil penelitian sebelumnya yang menunjukkan bahwa program pengajaran yang direncanakan membantu untuk mengurangi kecemasan ibu primigravida dan studi ini menunjukkan bahwa ada korelasi positif antara pengetahuan dan penurunan kecemasan menghadapi persalinan pada ibu primigravida. ${ }^{12}$ Hasil 
penelitian ini juga sesuai dengan hasil penelitian lain yang menyatakan bahwa psikoedukasi dapat menurunkan ansietas dari wanita primigravida yang akan melahirkan. ${ }^{18}$

Materi pendidikan kesehatan merupakan salah satu faktor yang berpengaruh terhadap tercapainya tujuan pendidikan kesehatan. ${ }^{19}$ Materi pendidikan kesehatan yang diberikan pada penelitian ini diantaranya adalah pengertian persalinan, tanda permulaan persalinan, tanda persalinan berlangsung, proses persalinan, tanda bahaya pada persalinan, persiapan persalinan dan upaya yang dilakukan untuk mengatasi nyeri persalinan. Dengan diberikan materi pendidikan tersebut ibu mengatakan mengerti dan memahami tentang proses melahirkan sehingga rasa cemasnya berkurang. Hal ini sesuai dengan pendapat yang menyatakan bahwa pendidikan kesehatan yang perawat berikan dapat meredakan kecemasan dan ketakutan akan proses kelahiran yang aman untuk dirinya dan bayinya serta takut mengalami nyeri selama proses bersalin atau mutilasi (hilangnya bagian tubuh) karena mereka tidak mengerti anatomi dan proses melahirkan. ${ }^{6}$ Pendapat ini juga didukung oleh hasil penelitian yang menyatakan bahwa faktor yang berkontribusi terhadap trauma psikologi selama melahirkan diantaranya adalah riwayat trauma jalan lahir dan dukungan sosial, nyeri pada fase pertama melahirkan, perasaan tidak berdaya, harapan, intervensi medis dan interaksi dengan petugas kesehatan dan dari hasil penelitian tersebut disarankan untuk melakukan skreening prenatal tentang riwayat post trauma, dukungan sosial dan harapan tentang melahirkan, serta meningkatkan komunikasi dan manajemen nyeri selama melahirkan sehingga dapat mencegah trauma psikologi selama melahirkan. ${ }^{13}$

Selain materi, metode juga merupakan faktor penentu tercapainya tujuan pendidikan kesehatan. Metode yang digunakan dalam penelitian ini adalah curah pendapat, ceramah, diskusi dan demonstrasi. Curah pendapat merupakan cara yang terbaik untuk membuka suatu masalah, dan mengumpulkan pendapat-pendapat tiap orang. Dengan cara ini semua konstribusi dari anggota kelompok dihargai sama, dan tiap orang mendapat suatu kesempatan untuk berpartisipasi. ${ }^{20}$ Dengan curah pendapat tersebut responden dapat mengungkapkan perasaannya sehingga peneliti dapat memberikan informasi baru sesuai yang diinginkan oleh responden melalui ceramah yang dilanjutkan dengan diskusi. Diskusi adalah metode pembelajaran dengan menekankan pada pembicaraan dua arah yang ditujukan untuk memecahkan masalah dalam bentuk pernyataan ataupun dalam bentuk pertanyaan. ${ }^{21}$ Dalam hal ini peneliti memberikan kesempatan pada responden untuk menanyakan hal-hal yang kurang jelas dan peneliti memberikan pertanyaan secara lisan tentang materi yang diberikan. Pada akhir pertemuan peneliti mendemonstrasikan ketrampilan upaya untuk mengatasi nyeri persalinan. Memberi kesempatan pada ibu dan keluarga untuk mendemonstrasikan kembali ketrampilan yang telah diajarkan peneliti.

Dengan menggunakan berbagai metode tersebut responden akan lebih mudah untuk mengerti dan memahami informasi yang diberikan, pengetahuan tentang persalinan dan melahirkan meningkat dan akan bersikap atau berpikir positif sehingga dapat menurunkan kecemasan. Hal ini sesuai dengan pernyataan yang disampaikan oleh WHO bahwa komunikasi kesehatan yang efektif jarang sekali dicapai dengan penggunaan satu metode saja, atau bahkan dua atau tiga metode. Keberhasilan pendidikan kesehatan tergantung pada kemampuan untuk menggabungkan berbagai metode baik metode langsung dan tidak langsung untuk mencapai tujuan pendidikan kesehatan..$^{22}$

Analisis statistika menggunakan uji independent t-test menunjukkan bahwa terdapat perbedaan yang bermakana pada selisih rata-rata kecemasan primigravida dalam menghadapi persalinan antara kelompok perlakuan dan kelompok kontrol yang berarti pendidikan kesehatan dengan booklet dapat menurunkan kecemasan primigravida dalam menghadapi persalinan lebih besar dibandingkan dengan pendidikan kesehatan tanpa booklet. 
Adanya perbedaan pada kelompok perlakuan dan kelompok kontrol dikarenakan pada kelompok perlakuan selain diberikan pendidikan kesehatan juga diberikan booklet pada setiap ibu hamil. Booklet memiliki beberapa kelebihan diantaranya adalah: 1) Dapat dipelajari setiap saat, karena desain berbentuk buku; 2) Memuat informasi relatif lebih banyak. Booklet umumnya digunakan dengan tujuan untuk meningkatkan pengetahuan tentang isu-isu kesehatan, karena booklet memberikan informasi dengan spesifik, dan banyak digunakan sebagai media alternatif untuk dipelajari setiap saat bila seseorang menghendakinya. ${ }^{23}$ Dengan demikian ibu hamil dapat mempelajari booklet tersebut setiap saat sehingga pengetahuan tentang proses persalinan meningkat dan kecemasan menurun. Hal ini sesuai dengan hasil penelitian sebelumnya yang menyatakan bahwa pendidikan kesehatan dengan booklet efektif untuk menurunkan kecemasan wanita hamil trimester III dalam menghadapi persalinan, booklet adalah media pendidikan kesehatan yang memuat informasi lebih banyak juga mudah dipahami. Seseorang dengan pengetahuan tinggi akan berfikir positif juga mempunyai koping positif sehingga dapat menurunkan kecemasan. ${ }^{24}$ Hasil penelitian ini juga sesuai dengan hasil penelitian lain, pada pasien infark myokard yang menyatakan bahwa kecemasan pada kelompok yang diberikan pendidikan kesehatan dengan metode tatap muka dan booklet yang diberikan kepada pasien berkurang dibandingkan dengan kelompok kontrol. ${ }^{25}$ Kondisi tersebut juga sesuai dengan pernyataan yang disampaikan oleh WHO bahwa penggunaan metode/media pendidikan sangat menentukan keberhasilan penyampaian pendidikan kesehatan. ${ }^{22}$

\section{KESIMPULAN DAN SARAN}

Pendidikan kesehatan dengan booklet dapat menurunkan kecemasan primigravida dalam menghadapi persalinan lebih besar dibandingkan dengan pendidikan kesehatan tanpa booklet. Dengan demikian penulis menyarankan untuk menggunakan booklet sebagai media dalam memberikan pendidikan kesehatan pada ibu primigravida saat antenatal care sehingga dapat mempersiapkan psikologis ibu dalam menghadapi persalinan.

\section{DAFTAR PUSTAKA}

1. Reeder, Martin \& Koniak-Griffin. Keperawatan Maternitas: Kesehatan Wanita, Bayi, \& Keluarga. Jakarta: EGC. 2011.

2. Musbikin, I. Persiapan Menghadapi Persalinan Dari Perencanaan Kehamilan Sampai Mendidik Anak. Yogyakarta: Mitra Pustaka. 2006.

3. Badan Pusat Statistik, BKKBN, Kemenkes RI, Measure DHS. Survei Demografi dan Kesehatan Indonesia. Calverton, Marylan, USA.2012.

4. Kemkes RI. Profil Kesehatan Indonesia 2012. Jakarta: Kementrian Kesehatan RI.

5. Dinkes Jombang. 2012. Profil Kesehatan Kabupaten Jombang Tahun 2012. Jombang: Dinkes Jombang.

6. Bobak, Lowdermilk \& Jensen. Buku Ajar Keperawatan Maternitas. Jakarta: EGC. 2005.

7. Kurki, T., Hiilesma, V., Raitasalo, R., Mattila, H. \& Ylikorkala, O. Depression and Anxiety in Early Pregnancy and Risk for Preeclampsia. Obstetrics \& Gynecology. 2000;95(4):487-490.

8. Helbig A., Kaasen A., Malt U.F. \& Haugen G. Does Antenatal Maternal Psychological Distress Affect Placental Circulation in the Third trimester?. Plos One.2013;8(2):1-7.

9. Coad, J. Anatomi dan Fisiologi untuk Bidan. Jakarta: EGC. 2006.

10. Chapman, V. Asuhan Kebidanan : Persalinan dan Kelahiran. Jakarta:EGC.2006.

11. Dayan, J., Creveuil, C., Herlicoviez, M., Herbel, C., Baranger, E., Savoye, E. \& Thouin, A. Role of Anxiety and Depression in the Onset of Spontaneous Preterm Labor. American Journal of Epidemiologi. 2002; 155: 293-301.

12. Gayathri, K.V., Raddi, S.A \& Metgud, M.C. Effectiveness of Planned Teaching Program on Knowledge and Reducing Anxiety about Labor among Primigravidae in Selected Hospitals of Belgaum, Karnataka. South Asian Federation of Obstetrics and Gynecology, 2010;2(2):163-168.

13. Soet, J.E., Brack, G.A. \& Diloria, C. Prevalence and Predictor of Women's Experience of Psycological Trauma During Chilbirth. Birth.2003;30(1):36-46. 
14. Suliha, Herawati, Sumiati \& Resnayati, Y. Pendidikan Kesehatan dalam Keperawatan. Jakarta: EGC. 2002.

15. Muhimah, N \& Safe'i. Panduan Lengkap Senam Hamil, Khusus Ibu Hamil. Jakarta: Power Book. 2010.

16. Simkin, Whalley \& Keppler. Kehamilan, Melahirkan, \& Bayi: Panduan Lengkap. Jakarta: Arcan.2008.

17. Maclellan, J. Antenatal Anxiety in Pregnant Women from Rural Cambodia. Britis Journal of Midwifery. 2010;18(11):735-743.

18. Martini, S. Pengaruh Psikoedukasi Dukungan pada Keluarga Terhadap Tingkat Kecemasan dan Kadar Kortisol Ibu Bersalin Primigravida Fase Laten di RSE Batam. Tesis. Surabaya: Fakultas Keperawatan Universitas Airlangga. 2011.

19. Notoatmodjo, S. IImu Kesehatan Masyarakat: IImu dan Seni. Jakarta: Rineka Cipta.2007.

20. Ewles, L. \& Simnett, I. Promosi Kesehatan, Petunjuk Praktis. Edisi Kedua. Yogyakarta: Gadjah Mada University Press.1994.

21. Setiawati, S. \& Darmawan, A.C. Proses Pembelajaran dalam pendidikan Kesehatan. Jakarta: Trans Info Media.2008.
22. WHO. Pendidikan Kesehatan, Pedoman Pelayanan Dasar (Alih Bahasa: Ida Bagus Tjitarsa). Bandung: Penerbit ITB-Universitas Udayana.1992.

23. Mintarsih, W. Pendidikan Kesehatan Menggunakan Booklet dan Poster dalam Meningkatkan Pengetahuan dan Sikap Remaja tentang Kesehatan Reproduksi di Kabupaten Tasikmalaya. Tesis. Yogyakarta: Fakultas Kedokteran Universitas Gadjah Mada.2007.

24. Hosentha, H. Pendidikan Kesehatan Media Booklet Terhadap Kecemasan Ibu Primigravida Trimester III dalam Menghadapi Persalinan. Surabaya: Fakultas Ilmu Keperawatan Universitas Airlangga.2011.

25. Vardanjani, S.A.E., Fanisaberi, L., Shahraki, F.A., Khalilzadeh, A., Vardanjani, A.T., \& Dehkordi, F.G. The Effect of Face-to-Face Education and Educational Booklet on Heart Health Indexes of TheHospitalized Patients with Myocardial Infarction. Nursing Research and Practice. 2013;2013:1-8. 